\title{
Long-term prognosis of 4 children with steroid-sensitive nephrotic syndrome and relapse after 30 years of age
}

\author{
Osamu Motoyama $\cdot$ Ken Sakai $\cdot$ Kikuo Iitaka
}

Received: 19 July 2013/Accepted: 19 August 2013/Published online: 14 September 2013

(C) The Author(s) 2013. This article is published with open access at Springerlink.com

\begin{abstract}
Some children with steroid-sensitive nephrotic syndrome (SSNS) have been reported to suffer relapses in adulthood, but the clinical course of such adults is unclear. Four children with SSNS suffered relapses after 30 years of age. Those 4 patients developed frequently relapsing nephrotic syndrome (NS) between 2 and 10 years of age. They were treated with prednisolone (PSL) combined with cyclophosphamide in 3 patients, mizoribine in 2, and cyclosporine in 1 during childhood, and with cyclosporine in 2 during adulthood. After 20 years of age, the frequency of relapses gradually decreased. The last relapse occurred between 33 and 39 years of age, and proteinuria disappeared within 1 month after the start of treatment with PSL. At the last follow-up, all 4 patients continued to receive PSL, had normal renal function, and were in complete remission of NS when they were between 33 and 41 years of age. Although the long-term outcome of SSNS is usually considered to be favorable, pediatricians should be aware that some children with SSNS may require longterm treatment during adulthood.
\end{abstract}

O. Motoyama ( $\square)$

Department of Pediatrics, Toho University Medical Center, Sakura Hospital, 564-1 Shimoshizu, Sakura, Chiba 285-8741, Japan

e-mail: motoyan@basil.ocn.ne.jp

K. Sakai

Department of Nephrology, Toho University Medical Center, Omori Hospital, Tokyo, Japan

K. Iitaka

Narse Renal Clinic, Tokyo, Japan
Keywords Childhood-onset nephrotic syndrome Steroid-sensitive nephrotic syndrome $\cdot$ Frequently relapsing nephrotic syndrome $\cdot$ Prognosis

\section{Introduction}

Long-term outcome of steroid-sensitive nephrotic syndrome (SSNS) is usually considered to be good. Relapses of SSNS become less frequent towards puberty, and eventually permanent remission is achieved. Recent reports have shown that almost one-third of children with SSNS suffer a relapse during adulthood $[1,2]$. The clinical course in adult patients with childhood-onset SSNS is unclear.

\section{Case report}

Four patients with childhood-onset SSNS had a relapse after 30 years of age (Table 1). Nephrotic syndrome (NS) was diagnosed in patients who had heavy proteinuria (more than $40 \mathrm{mg} / \mathrm{m}^{2} / \mathrm{h}$ ) and hypoalbuminemia (serum albumin $<2.5 \mathrm{~g} / \mathrm{dL}$ ). Patients who responded during 8 weeks of prednisolone (PSL) treatment were defined as SSNS. Relapse was defined as a reappearance of proteinuria $(2+$ or greater by dipstick for 3 consecutive days). Frequent relapses were defined as two or more relapses within the first 6 months after initial response or four or more relapses during any 12-month period [3]. All four patients were treated with PSL $\left(60 \mathrm{mg} / \mathrm{m}^{2} /\right.$ day $)$ until remission was achieved. PSL was then tapered using alternate-day doses over a six-week period. The first relapse was treated the same as the initial treatment. The PSL was tapered more slowly and the dose of PSL was determined individually according to the threshold at which the relapse occurred. 
Table 1 Profiles of 4 children with relapse of nephrotic syndrome after 30 years of age

\begin{tabular}{|c|c|c|c|c|}
\hline & Case 1 & Case 2 & Case 3 & Case 4 \\
\hline Sex & Male & Male & Female & Female \\
\hline Age at onset & 6 years & 2 years & 2 years & 10 years \\
\hline $\begin{array}{l}\text { Number of } \\
\text { relapses }\end{array}$ & 35 & 53 & 51 & 44 \\
\hline $\begin{array}{l}\text { Frequent } \\
\text { relapser }\end{array}$ & + & + & + & + \\
\hline $\begin{array}{l}\text { Renal biopsy } \\
\text { finding }\end{array}$ & FSGS & - & - & - \\
\hline Treatment & $\begin{array}{l}\text { PSL, CY, MZ, } \\
\text { CyA }\end{array}$ & $\begin{array}{l}\text { PSL, CY, } \\
\text { MZ }\end{array}$ & $\begin{array}{l}\text { PSL, CY, } \\
\text { CyA }\end{array}$ & $\begin{array}{l}\text { PSL, } \\
\text { CyA }\end{array}$ \\
\hline $\begin{array}{l}\text { Age at last } \\
\text { relapse }\end{array}$ & 39 years & 35 years & 34 years & 33 years \\
\hline $\begin{array}{l}\text { Age at last } \\
\text { follow-up }\end{array}$ & 41 years & 36 years & 35 years & 33 years \\
\hline
\end{tabular}

FSGS focal segmental glomerulosclerosis, $C Y$ cyclophosphamide, $M Z$ mizoribine, $C y A$ cyclosporine

Estimated glomerular filtration rate was calculated by the method of Matsuo et al. [4]. The standard deviation (SD) in patient height was calculated using the mean Japanese adult height of $170.8 \pm 5.8 \mathrm{~cm}$ for males and $158.1 \pm$ $5.3 \mathrm{~cm}$ for females.

Their ages at the onset of NS ranged between 2 and 10 years. Neither hypertension, hematuria, nor renal failure was noted in these 4 patients. Anti-nuclear antibody was negative and serum IgA and complement levels were normal. The number of relapses of NS was between 35 and 53, and frequently relapsing NS was noted in all patients. Renal biopsy was not performed in cases 2-4. They were treated with PSL combined with cyclophosphamide (CY) in 3 patients (cases 1-3), mizoribine (MZ) in 2 (cases 1 and 2), and cyclosporine (CyA) in 3 (cases 1 , 3 , and 4). CY at a dose of $2 \mathrm{mg} / \mathrm{kg}$ for 8-12 weeks, $\mathrm{MZ}$ at a dose of $100 \mathrm{mg} / \mathrm{m}^{2}$, and CyA at a dose to target the trough level of $100 \mathrm{ng} / \mathrm{mL}$ were used. The total dose $(\mathrm{mg} /$ $\mathrm{kg}$ ) of CY was 430 in case 1, 275 in case 2, and 90 in case 3. A microemulsion formulation of CyA was used in case 1. Cases 3 and 4 were treated with CyA before the microemulsion formulation was developed. Relapse was noted until 39 years old in case 1. PSL was tapered more slowly in adulthood than in childhood. During adulthood, CyA was used for 1-2 years in cases 1 and 4. After 20 years of age, the frequency of relapses gradually decreased (Table 2). At the last relapse, proteinuria disappeared promptly after the start of PSL (Table 3). Their adult heights were between -1.6 and 0.7 SD. Case 1 was obese (body mass index of 30) and was treated with antihypertensive drugs. At the last follow-up, all 4 patients continued to receive PSL, had normal renal function, and were in complete remission from NS, when they were
Table 2 Number of relapses per year in each decade of age

\begin{tabular}{lllll}
\hline & $0-9$ years & $10-19$ years & $20-29$ years & $30-39$ years \\
\hline Case 1 & 1.7 & 1.8 & 0.9 & 0.2 \\
Case 2 & 3.6 & 1.7 & 0.6 & 0.3 \\
Case 3 & 1.4 & 2.3 & 1.1 & 1.0 \\
Case 4 & - & 2.0 & 2.0 & 1.5 \\
\hline
\end{tabular}

Table 3 Dose of prednisolone and response to treatment with prednisolone at the onset of nephrotic syndrome and at last relapse

\begin{tabular}{|c|c|c|c|c|}
\hline & \multicolumn{2}{|l|}{ At onset } & \multicolumn{2}{|l|}{ At last relapse } \\
\hline & $\begin{array}{l}\text { Prednisolone } \\
\left(\mathrm{mg} / \mathrm{m}^{2}\right)\end{array}$ & $\begin{array}{l}\text { Time to } \\
\text { induce } \\
\text { remission }\end{array}$ & $\begin{array}{l}\text { Prednisolone } \\
\left(\mathrm{mg} / \mathrm{m}^{2}\right)\end{array}$ & $\begin{array}{l}\text { Time to } \\
\text { induce } \\
\text { remission }\end{array}$ \\
\hline Case 1 & $\begin{array}{l}45 \mathrm{mg} / \text { day } \\
(46.9)\end{array}$ & 6 days & $\begin{array}{l}20 \mathrm{mg} / \text { day } \\
(9.7)\end{array}$ & 10 days \\
\hline Case 2 & $\begin{array}{l}30 \mathrm{mg} / \text { day } \\
(55.6)\end{array}$ & 8 days & $\begin{array}{c}40 \mathrm{mg} / \text { day } \\
(22.7)\end{array}$ & 9 days \\
\hline Case 3 & $\begin{array}{c}30 \mathrm{mg} / \text { day } \\
(51.7)\end{array}$ & 7 days & $5 \mathrm{mg} /$ day (3.6) & $<4$ weeks $^{\text {b }}$ \\
\hline Case 4 & $\begin{array}{c}60 \mathrm{mg} / \text { day } \\
(54.5)\end{array}$ & 9 days & $\begin{array}{c}45 \mathrm{mg} / \text { day } \\
(30.4)\end{array}$ & 7 days \\
\hline
\end{tabular}

a Time from the start of treatment with prednisolone

b Proteinuria was not tested until 4 weeks after treatment with prednisolone

Table 4 Clinical findings at last follow-up

\begin{tabular}{lllll}
\hline & Case 1 & Case 2 & Case 3 & Case 4 \\
\hline Height (standard deviation) & 0.7 & -0.8 & -1.6 & -1.5 \\
Body mass index $\left(\mathrm{kg} / \mathrm{m}^{2}\right)$ & 30 & 24 & 19 & 22 \\
Blood pressure $(\mathrm{mmHg})$ & $132 / 76$ & $130 / 76$ & $90 / 40$ & $120 / 70$ \\
Antihypertensive agents & ARB etc. & - & - & - \\
Serum creatinine $(\mathrm{mg} / \mathrm{dL})$ & 0.7 & 0.7 & 0.6 & 0.5 \\
eGFR $\left(\mathrm{mL} / \mathrm{min} / 1.73 \mathrm{~m}^{2}\right)$ & 100 & 99 & 99 & 113 \\
Proteinuria & - & - & - & - \\
Treatment & & & & \\
Prednisolone $(\mathrm{mg} /$ day) & 2.5 & 15 & 2 & 10 \\
Cyclosporine (mg/day) & 200 & - & - & - \\
\hline
\end{tabular}

$A R B$ angiotensin-receptor blocker, $e G F R$ estimated glomerular filtration rate

between 33 and 41 years of age (Table 4). They were not admitted for relapses during adulthood, except for 1 admission for the 33rd relapse of case 1 . Three patients (cases 1-3) were working full-time. Case 4 was a housewife with two children. Case 2 also had 2 children. Two of the patients (cases 1 and 3) were not married. There were no signs nor symptoms of insufficiency fracture, aseptic necrosis of femoral capital epiphyses, glucose intolerance, cataract, or malignant diseases in any of the 4 patients. 


\section{Case 1}

CY was used at the age of 7 and 10 years, and MZ between the age of 19 and 20 years. He had a 33rd relapse at the age of 29 years, and renal biopsy showed focal segmental glomerulosclerosis. His body mass index was over 30 and his renal function remained normal. Proteinuria disappeared 1 week after treatment with PSL. Focal segmental glomerulosclerosis associated with obesity was suspected [5]. An angiotensin-converting enzyme inhibitor was added after the complete remission of NS. At his 34th relapse at 34 years old, he went into complete remission within 2 weeks after the treatment with PSL, and PSL was tapered for 3 years. At his 35th relapse at 39 years old, CyA was started, and angiotensin-converting enzyme inhibitor was changed to angiotensin-receptor blocker and calcium channel blocker.

\section{Case 2}

He was treated with CY at 8 and 15 years of age and MZ for 1 year at 13 years of age. He had 6 relapses between 20 and 29 years of age. He developed his 52nd relapse at 31 years of age and was treated with PSL for 8 months. His daughter also developed SSNS [6]. At 35 years of age, his 53rd relapse occurred, and PSL was on a tapering dose at the last follow-up.

\section{Case 3}

CY, followed by CyA for 1 year, was used for growth impairment due to continuous treatment with PSL at $5-10 \mathrm{mg} /$ day at 13 years of age [7]. Her adult height reached -1.6 SD. After 30 years of age, 6 relapses occurred when PSL was tapered to $1 \mathrm{mg} /$ day. At her 51st relapse in 34 years old, she was treated with PSL $5 \mathrm{mg}$ / day, and her proteinuria disappeared within 1 month. She was on PSL $2 \mathrm{mg} / \mathrm{day}$ at the last follow-up.

\section{Case 4}

CyA was used between 24 and 25 years of age. She had 4 relapses during treatment with $\mathrm{CyA}$, and CyA was discontinued at her first pregnancy. She had relapses during pregnancy at 26 and 31 years of age and received PSL treatment. She delivered a normal baby in 2 pregnancies [8]. After her second delivery, PSL was withdrawn. Her 42nd to 44th relapses occurred between 32 and 33 years of age, and PSL treatment was restarted.

\section{Discussion}

Relapses of SSNS become less frequent towards puberty, and eventually permanent remission is achieved. Studies from the 1980s reported that no more than $10 \%$ of children had additional relapses in adulthood. More recent reports indicated a relapse rate after 18 years of age of between 27 and $42 \%[1,2]$. Most patients who have relapsed during adulthood developed NS at a young age and were frequent relapsers during childhood [2, 9, 10]. Between 1972 and 2013, 148 patients were diagnosed with SSNS before 15 years of age at Toho University Omori Hospital and Sakura Hospital. Of the 34 patients who were followed after 20 years of age, 12 had at least one relapse after 20 years. The mean onset age for the 12 patients was $6.8 \pm 3.6(2.2-12.7)$ years, and 11 of them were frequent relapsers. Of the 5 patients who relapsed after 20 years of age and were followed after 30 years of age, 4 patients had one or more relapses after 30 years. To our knowledge, only a few patients who relapsed after 30 years of age have been reported. Relapses in a 33-year-old patient and a 39 -year-old patient were reported $[9,11]$. Kyrieleis et al. [12] reported 5 patients whose onsets of frequently relapsing minimal change nephrotic syndrome (MCNS) ranged between 1 and 3 years of age, and who had relapses between 32 and 42 years of age. However, the clinical courses of these patients in adulthood were not described.

Patients with adult-onset MCNS who have transient hypertension and impaired renal function during the nephrotic phase are not rare, and therapeutic response is slower than in children. According to a report by the International Study of Kidney Disease in Children, $85-90 \%$ of children with NS achieved complete remission within 4 weeks and 90-95\% within 8 weeks after the start of steroid treatment. In adult patients with MCNS, response to steroid treatment may take up to 15 weeks. In some studies of adult patients given PSL, remission occurred in $50-60 \%$ of patients after 8 weeks of treatment, and in $70-75 \%$ after 16 weeks [13]. In the 4 patients presented here, the time period from the start of treatment with PSL to the induction of complete remission was similar to that of childhood NS. Frequency of relapse decreased with age, and renal function was normal after 30 years of age. The prognosis was similar to the children with SSNS, despite their prolonged course of NS. There does not seem to be any proven way to predict the individual relapse courses of patients with SSNS at onset [1]. Evaluating the number of relapses during a long-term course, as shown in Table 2 of this report, may predict the frequency of relapse during adulthood in some patients.

Both increased duration and a higher dose of PSL treatment leads to prolonged remission. The Cochrane database of systematic reviews suggested that duration of 
PSL therapy was more important than the dose of PSL. In children with SSNS treated with PSL for 7 months, frequency of relapse over the course of 2 years significantly decreased compared with that for SSNS children treated with PSL for 2 months [14]. At relapse in adult patients, PSL should be continued for 7 months.

Case 1 presented here suffered a relapse at 39 years of age, and a relapse in a 42-year-old patient has also been reported [12]. Although the long-term outcome of SSNS is usually considered to be favorable, the chronic course and prolonged treatments involved affect the quality of life of children and also that of their families. Prolonged steroid treatment may cause short stature, obesity, and hypertension in adulthood [2]. Social performance and quality of life seemed to be relatively good in the 4 patients reported here. Pediatricians should be aware that some children with SSNS may require long-term treatment even after they have entered adulthood.

Conflict of interest The authors have declared that no conflict of interest exists.

Open Access This article is distributed under the terms of the Creative Commons Attribution License which permits any use, distribution, and reproduction in any medium, provided the original author(s) and the source are credited.

\section{References}

1. Vogt BA, Avner ED. Conditions particularly associated with proteinuria. In: Kliegman RM, Jenson HB, Behrman RF, Stanton BF, editors. Nelson textbook of pediatrics. 18th ed. Philadelphia: Saunders; 2007. p. 2188-95.

2. Niaudet P. Long-term outcome of children with steroid-sensitive idiopathic nephritic syndrome. Clin J Am Soc Nephrol. 2009;4:1547-8.

3. Hogg RJ, Portman RJ, Milliner D, Lemley KV, Eddy A, Ingelfinger J. Evaluation and management of proteinuria and nephrotic syndrome in children: recommendations from a pediatric nephrology panel established at the National Kidney Foundation conference on proteinuria, albuminuria, risk, assessment, detection, and elimination (PARADE). Pediatrics. 2000;105:1242-9.

4. Matsuo S, Imai E, Horio M, Yasuda Y, Tomita K, Nitta K, et al. Revised equations for estimated GFR from serum creatinine in Japan. Am J Kidney Dis. 2009;53:982-92.

5. Motoyama O, Muto A, Ogiwara H, Mizuiri S, Kawamura S, Iitaka K. A male patient with steroid-dependent nephrotic syndrome for 25 years and obesity-associated focal segmental glomerulosclerosis. Clin Exp Nephrol. 2004;8:263-5.

6. Motoyama O, Sugawara H, Hatano M, Fujisawa T, Iitaka K. Steroid-sensitive nephrotic syndrome in two families. Clin Exp Nephrol. 2009;13:170-3.

7. Motoyama O, Shigetomi Y, Iitaka K. Cyclosporin treatment in steroid-dependent nephrotic syndrome of childhood. Effective CyA concentration (whole blood, monoclonal RIA) and the effect of growth velocity. J Jpn Pediatr Soc. 1997;101:1303-7 (in Japanese with English abstract).

8. Motoyama O, Iitaka K. Pregnancy in 4 women with childhoodonset steroid-sensitive nephrotic syndrome. CEN Case Rep. 2013; doi: 10.1007/s13730-013-0087-9.

9. Matsukura H, Inaba S, Shinozaki K, et al. Influence of prolonged corticosteroid therapy on the outcome of steroid-responsive nephrotic syndrome. Am J Nephrol. 2001;21:362-7.

10. Fakhouri F, Bocquet N, Taupin P, Presne C, Gagnadoux MF, Landais $\mathrm{P}$, et al. Steroid-sensitive nephrotic syndrome. From childhood to adulthood. Am J Kidney Dis. 2003;41:550-7.

11. Kwong VWK, Kwan BCH, Chow KM, Leung CB, Li PKT, Szeto CC. Long-term outcome of biopsy-proven minimal-change nephrotic syndrome in Chinese children. Hong Kong J Nephrol. 2013;15:22-7.

12. Kyrieleis HAC, Löwik MM, Pronk I, Cruysberg HRM, Kremer JAM, Oyen WJG, et al. Long-term outcome of biopsy-proven, frequently relapsing minimal-change nephrotic syndrome in children. Clin J Am Soc Nephrol. 2009;4:1593-600.

13. Nachman PH, Jennette JC, Falk RJ. Primary glomerular disease. In: Taal MW, Chertow GM, Marsden PA, Skorecki K, Yu ASL, Brenner BM, editors. Brenner \& Rector's the kidney. 9th ed. Philadelphia: Elsevier Saunders; 2012. p. 1100-91.

14. Hodson EM, Craig JC, Willis NS. Evidence-based management of steroid-sensitive nephrotic syndrome. Pediatr Nephrol. 2005; $20: 1523-30$. 